\title{
AEROMAGNETIC MAP OF PART OF THE FISH RIVER LAKE QUADRANGLE, AROOSTOOK COUNTY, MAINE
}

\author{
By
}

L. A. Anderson, N. W. Natof, and others

GEOPHYSICAL INVESTIGATIONS

MAP GP-371

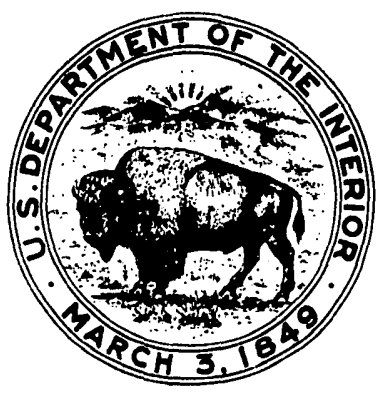

PUBLISHED BY THE U. S. GEOLOGICAL SURVEY 